\title{
Solution growth technique for iron copper sulphide ternary thin film and its optical characteristics
}

\author{
Uhuegbu, Chidi. C \\ Department of Physics, Covenant University, Ota Ogun State Nigeria \\ E-mail address: cuhuegbu@yahoo.co.uk
}

\begin{abstract}
Ternary thin films of Iron Copper Sulphide were grown on glass substrate using cheap and simple solution growth technique with EDTA, TEA and $\mathrm{NH}_{3}$ as complexing agents. The deposited films were characterized using PYE-UNICO-UV-2102 PC Spectrophotometer and optical microscopy. The optical properties considered revealed high absorbance and reflectance but low transmittance in the UV; low values of absorbance and reflectance accompanied with high transmittance in the VIS. Over all, the absorptive coefficient ranged from $0.1 \times 10^{6}$ to $1.65 \times 10^{6} \mathrm{~m}^{-1}$, the real part of the refractive index ranged from 1.2 to 2.3 , the optical conductivity ranged from $0.03 \times 10^{14} \mathrm{~s}^{-1}$ to $0.6 \times 10^{14} \mathrm{~s}^{-1}$, the extinction coefficient ranged from 0.005 to 0.038 , its direct band gap ranged from $2.4 \mathrm{eV}$ to $2.8 \mathrm{eV}$, the indirect band gap ranged from $0.6 \mathrm{eV}$ to $1.0 \mathrm{eV}$ and its complex dielectric constant from $(1.4+\mathrm{j} 0.005)$ to $(5.2+\mathrm{j} 0.136)$. These properties suggest that the films are suitable for solar cell applications.
\end{abstract}

Keywords: FeCuS thin film; Optical Properties; Band gap; Solution Growth Technique

\section{INTRODUCTION}

Solar energy can be converted directly to heat called solar thermal, or to electricity, called solar photovoltaic. Thin films are popular and effective transducers for the harnessing of solar energy. In all cases, the total energy captured by these transducers are directly proportional to the surface area, hence all solar energy devices must have a large surface area in order to produce significant energy.

Thin films are crystalline or non-crystalline material developed two dimensionally on a substrate surface by physical or chemical method. The preparation and study of physical properties of ternary chalcogenide compounds has increased in recent years [1-4]. Ternary compounds are found to be suitable material for optoelectronic device applications and good material for window layer solar cells [5]. Some of the films are investigated for use as super-ionic conducting materials [6-11]. The ternary compounds had been studied for efficient solar energy conversion materials [12-15]. Although, the deposition of ternary thin films have been reported using advanced technologies.

In the work reported here, the determination of the optical and solid state properties of the film were based on equations found in the literature [16-36].
Experiment: There are several methods of growing thin films, but the one used in this research is solution growth technique (SGT) which is basically a modification of the well known process of chemical precipitation.

The solution growth deposition of the thin film onto the glass substrate was carried out by using a mixture of $5 \mathrm{mls}$ of $1 \mathrm{M}$ ferrous nitrate, $5 \mathrm{mls}$ of $1 \mathrm{M}$ cuprous chloride, $3 \mathrm{mls}$ of $0.1 \mathrm{M}$ EDTA, $3 \mathrm{mls}$ of $7.4 \mathrm{M}$ TEA, $3 \mathrm{mls}$ of $14 \mathrm{M}$ ammonia, $10 \mathrm{mls}$ of $1 \mathrm{M}$ thiourea and $20 \mathrm{mls}$ of distilled water in a beaker. The glass substrate had been previously degreased in concentrated nitric acid $\mathrm{HNO}_{3}$ for 48 hours, cleaned in cold water with detergent, rinsed with distilled water and dried in air. The degreased-cleaned surface provide nucleation centre for growth of the film, hence yielding highly adhesive and uniformly deposited films.

The mixture was thoroughly stirred with the glass rod before the glass slide was vertically introduced into the beaker. However, the addition of TEA and EDTA as complexing agents slowed down the precipitation. Ammonia solution stabilizes the $\mathrm{pH}$ of the mixture. The chemical reaction involved in the deposition processes are as follows:

$\mathrm{Fe}\left(\mathrm{NO}_{3}\right)_{3} \cdot 9 \mathrm{H}_{2} \mathrm{O}+\mathrm{EDTA}=====[\mathrm{Fe}(\mathrm{EDTA})]^{+}+\mathrm{NO}_{3}{ }^{-}$ $[\mathrm{Fe}(\mathrm{EDTA})]^{+}=====\mathrm{Fe}^{3+}+\mathrm{EDTA}^{2-}$ 
$\mathrm{CuCl} \cdot 2 \mathrm{H}_{2} \mathrm{O}+$ TEA $====[\mathrm{Cu}(\text { TEA })]^{+}+\mathrm{Cl}^{-}$

$[\mathrm{Cu}(\mathrm{TEA})]^{+}=====\mathrm{Cu}^{+}+\mathrm{TEA}$

$\left(\mathrm{NH}_{2}\right)_{2} \mathrm{CS}+\mathrm{OH}^{-}====\left(\mathrm{NH}_{2}\right)_{2} \mathrm{CO}+\mathrm{HS}$

$\mathrm{HS}^{-}+\mathrm{OH}^{-}=====\mathrm{H}_{2} \mathrm{O}+\mathrm{S}^{2-}$

$\mathrm{Fe}^{3+}+\mathrm{Cu}^{+}+2 \mathrm{~S}^{2-}===\mathrm{FeCuS}_{2}$

\section{RESULTS AND DISCUSSION}

FeCuS1, FeCuS2 and FeCuS3 are used to represent sample 1, 2 and 3 respectively.

The graphs of spectral absorbance, transmittance and reflectance versus wavelength are presented in Figures 1, 2 and 3 respectively. The optical properties considered in figures-1, 2 and 3 revealed high absorbance and reflectance but low transmittance in the UV; low values of absorbance and reflectance accompanied with high transmittance in the VIS. The absorption coefficient ranged from $0.1 \times 10^{6} \mathrm{~m}^{-1}$ to $1.65 \times 10^{6} \mathrm{~m}^{-1}$ as shown in fig. 4 . The real part of the refractive index ranged from 1.2 to 2.3 as seen in fig. 5. The corresponding value of optical conductivity ranged from $0.03 \times 10^{14} \mathrm{~s}^{-1}$ to $0.6 \times 10^{14} \mathrm{~s}^{-1}$ as seen in fig. 6 . In fig. 7 , the extinction coefficient ranged from 0.005 to 0.038 . The direct and indirect band gaps ranged from $2.4 \mathrm{eV}$ to $2.8 \mathrm{eV}$ and $0.6 \mathrm{eV}$ to $1.0 \mathrm{eV}$ as shown in fig. 8 and fig. 9 respectively. The real and imaginary parts of the dielectric constant ranged from 1.4 to 5.2 and 0.008 to 0.136 as shown in fig. 10 and fig. 11 respectively. The thickness (t) ranged from $0.0103 \mu \mathrm{m}$ to $0.873 \mu \mathrm{m}$.

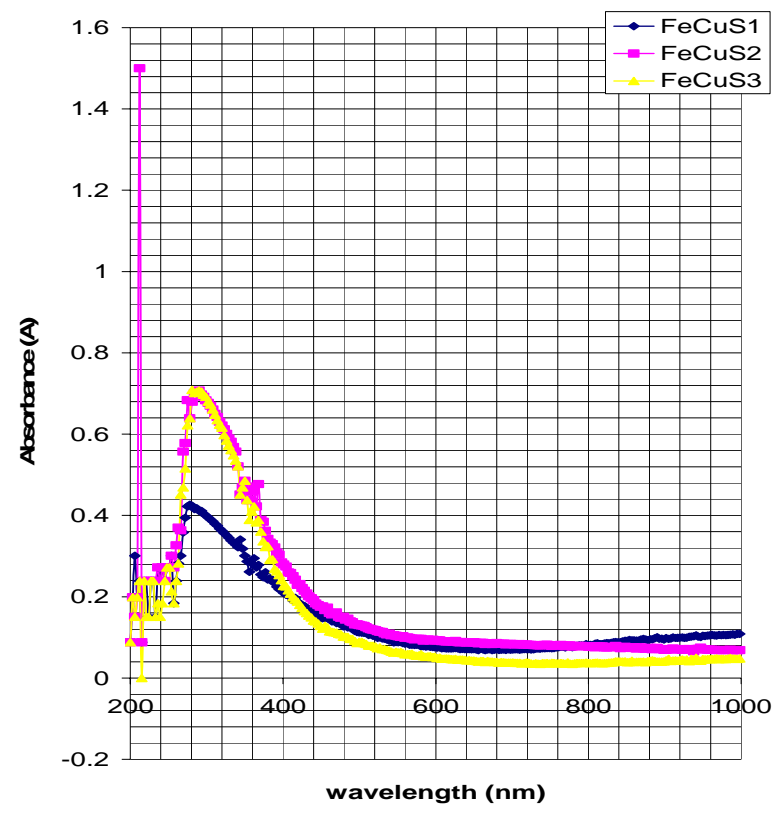

Figure 1 : Absorbance (A) as function of wavelength for FeCus Thin Film

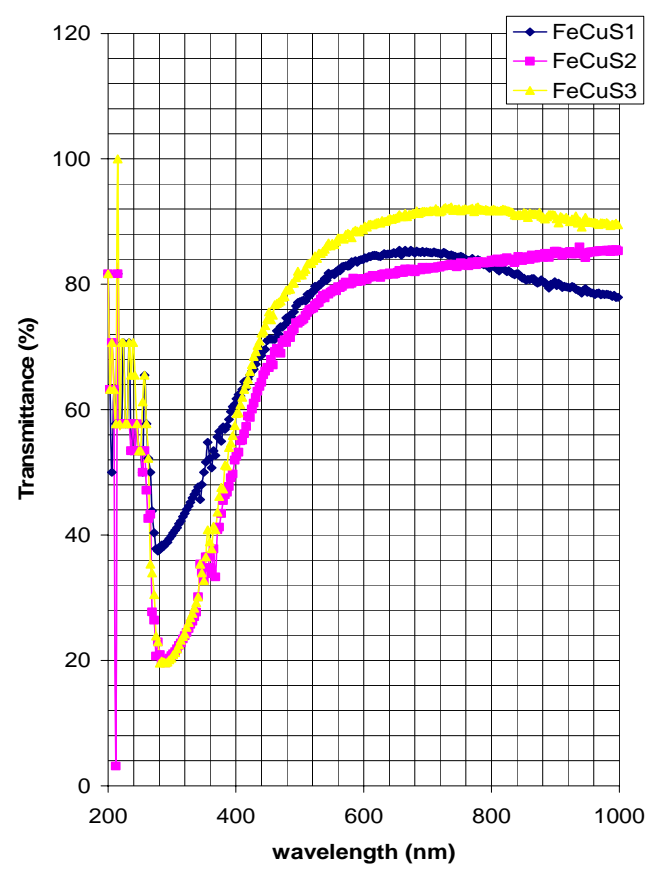

igure 2 : Transmittance $(T)$ as function of wavelength for FeCuS Thin Film

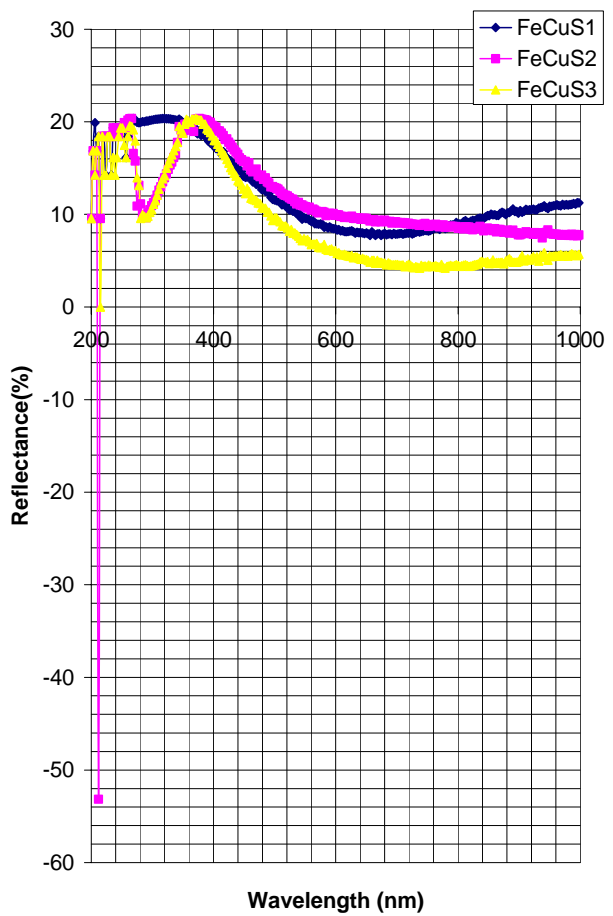

Figure 3 :Reflectance (R) as function of wavelength for FeCus Thin Film 
Am. J. Sci. Ind. Res., 2010, 1(3): 392-396
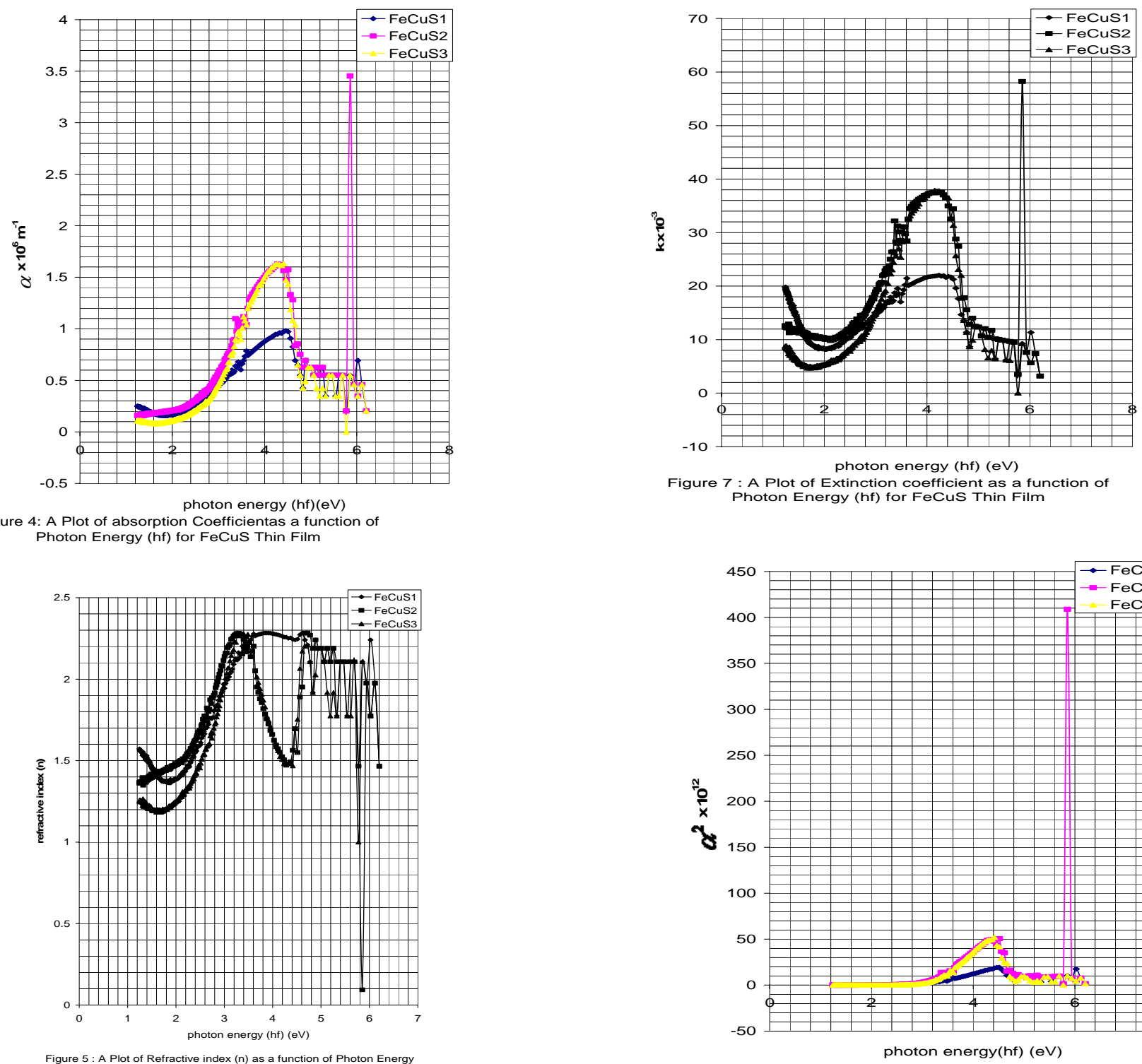

Figure 5: A Plot of Refractive index (n) as a function of Photon Energy
(hf) for FeCuS Thin Film

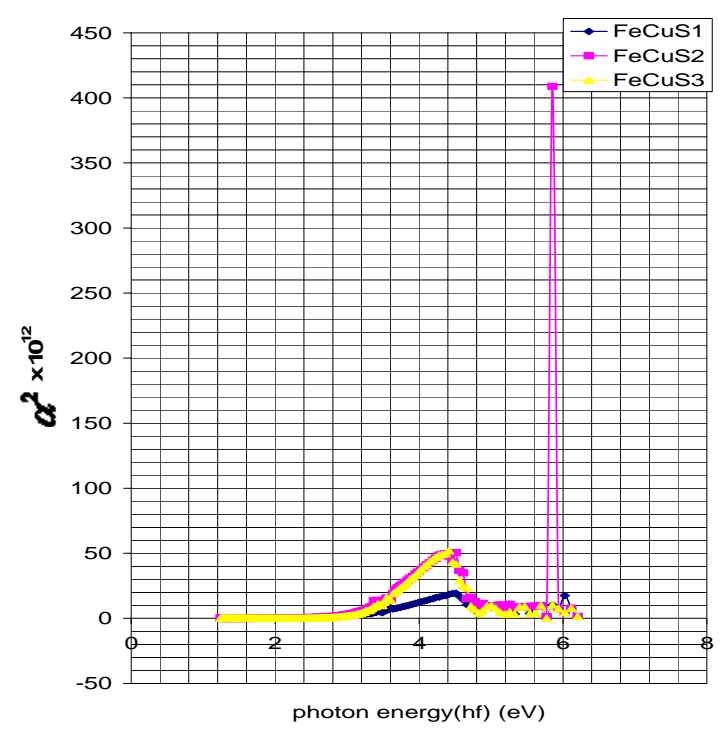

Ire 8: A Plot of [absorption Coefficient $)^{2}$ as a function of

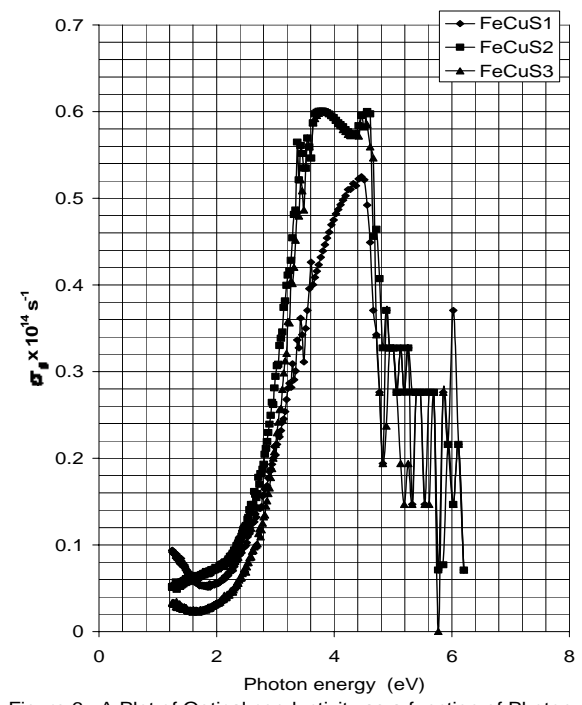
Photon Energy (hf) for FeCuS Thin Film

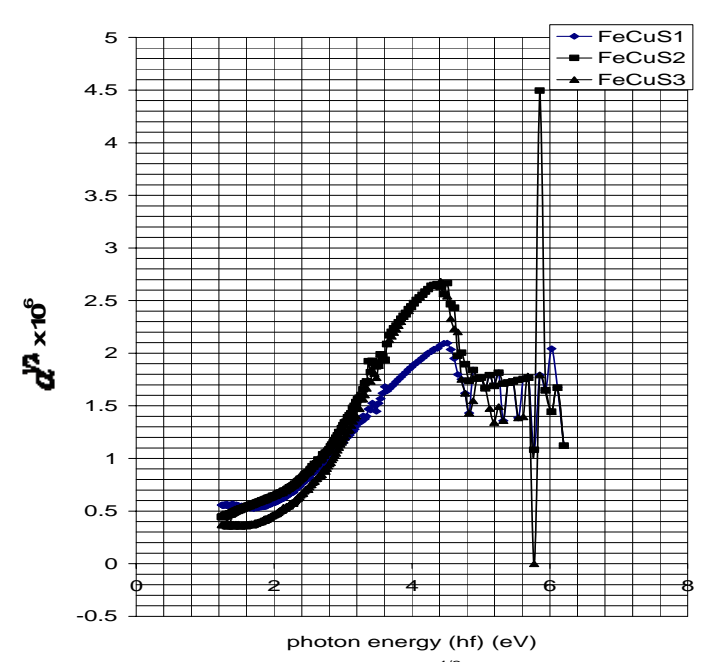

Figure 9: A Plot of (absorption Coefficient) (1/2 $^{1 / 2}$ as a function of Energy (hf) for FeCuSThin Film 


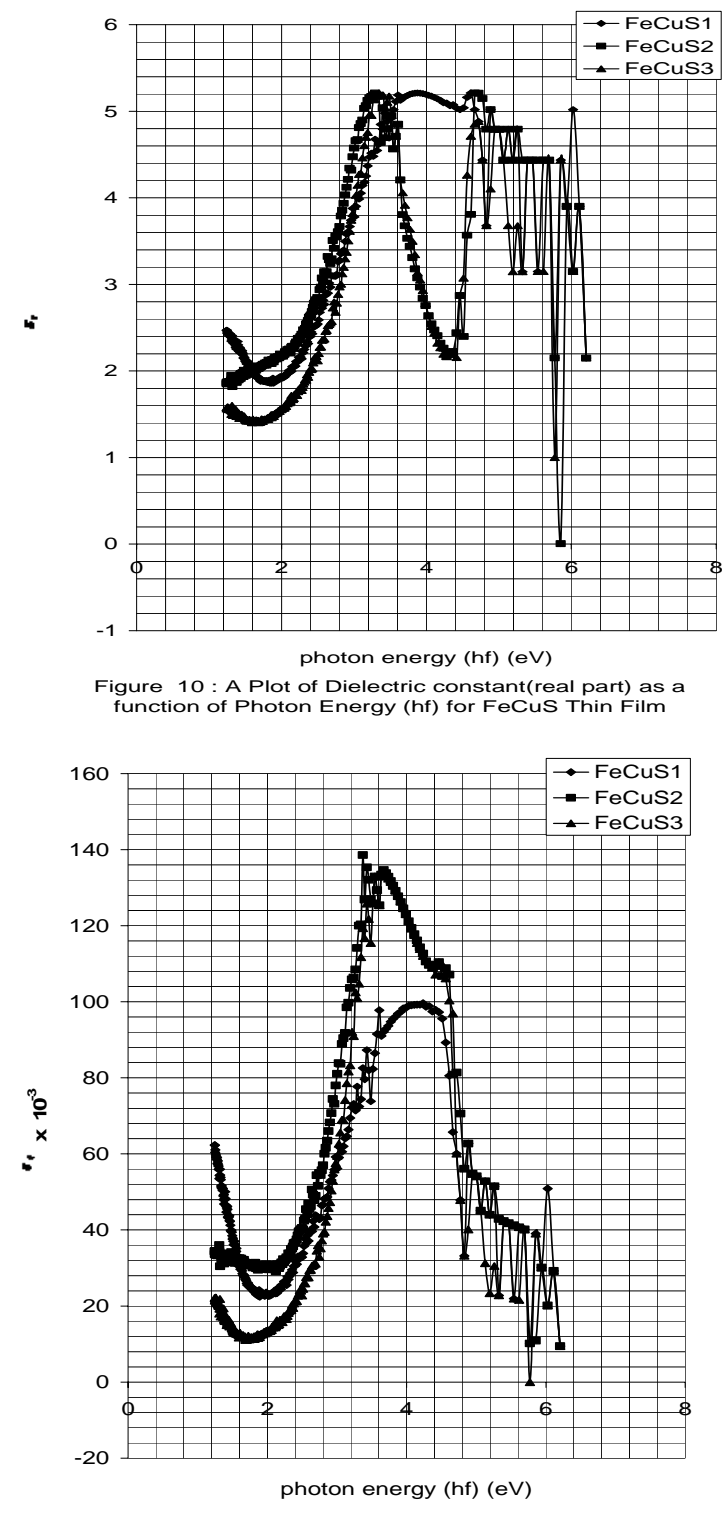

Figure 11: A Plot of Dielectric constant (imaginary part) as a function of Photon Energy (hf) for FeCuS Thin Film

These results above suggest that the thin films can suitably be applied for following: (i) solar cell fabrication, (ii) for the screening off UV radiation that is harmful to human beings and animals, (iii) optoelectronic devices, (iv) architectural design for cooling or heating buildings etc. This deduction agrees with the findings of other researchers on similar films [17, 22]. The films were found to be photo-conducting with voltage ranging from $0.1 \mathrm{mV}$ to $0.6 \mathrm{mV}$ inside the room and $0.6 \mathrm{mV}$ to $15 \mathrm{mV}$ outside the room around 9.30 am. The variations observed from the graphs may be due to variation in concentrations and impurities from the environment where the experiment is carried out
Conclusion: New ternary thin films of Iron Copper Sulphide have been grown on glass substrate using solution growth technique (SGT) and characterized using a spectrophotometer. From these results, it can be said that the thin films have the property of screening off UV portion of the electromagnetic radiation by absorbing and reflecting and admittance of the visible and infrared radiation by transmission. These properties confirms the films good materials for coating poultry buildings, eye glasses coating, solar thermal conversion, solar control, anti-reflection coating and solar cells fabrication.

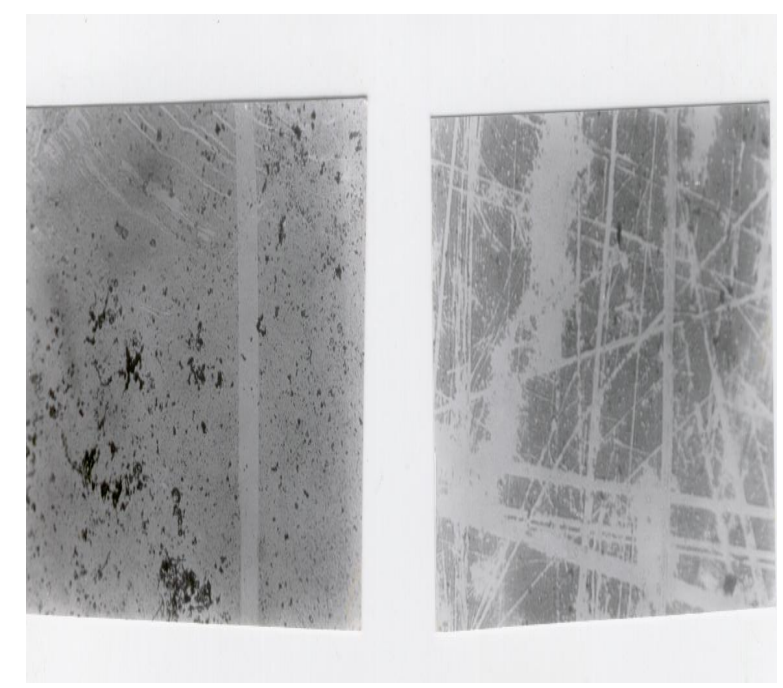

Fig 12 : Photomicrograph of fecus thin film revealing the crystalline nature

\section{REFERENCES}

[1] L. Ortega, M.O. Vigil Galan, F.Cruz-Gandarilla and O. Solorza-Fera, Material Research Bulletin, 38 (2003) 55

[2] P. K. Nair and M. T. S. Nair, Semicond. Sci. Technol. 7 (1992) 239

[3] F. I. Ezema, Academic open internet journal, http://www.acadjournal.com/2004/v11/part2/p1/index/h $\underline{\mathrm{tm}}$.

[4] A. Cruz-Vazquez, F. Rocha-Alonzo, S.E. Burruel-Ibarra, M. Inoue and R. Bernal, Superficies Y Vacio, 13 (2001) 89

[5] J. Woon-Jo and P. Cye-Choon, Solar Ener. Mater. and Solar Cells 75 (2003) 93

[6] T. Sasaki, H. Takizawa, T. Takeda and T. Endo, Material Research Bulletin 38 (2003) 33

[7] P. K. Nair, M. Ocampo, A. Fermandez and M. T. S. Nair, Sol. Ener. Mater. 20 (1990) 235 
[8] P. S. Pramanik, R. N. Bhattacharya and P. K. Basu, Thin Solid Films 149 (1987) 181

[9] F. I. Ezema and P. U. Asogwa, Pacific Journal of Science and Technology 5(1) (2004) 33

[10] I. C. Ndukwe, Sol. Ener. Mater. and Sol. Cells 40 (1996) 123

[11] C. C. Uhuegbu and C. E. Okeke, Nig. Journal of Phys. 7 (1995) 24

[12] G. K. Padam and S. U. M. Rao, Sol. Ener. Mater. 13 (1986) 297

[13] V. Estrella, M. T. S. Nair and P. K. Nair, Semicond. Sci. Technol. 18 (2003) 190

[14] S. H. Pawar, S. P. Tamhankar and C. D. Lokhande, Sol. Ener. Mater. 14 (1986) 71

[15] Lee. Jae-Hyeong, Song. Woo-Chang, Yi. Jun-Sin and Yoo. Yeong-Sik, Materials and Solar Cells 75(1-2) (2003) 227

[16] J. I. Pankove, Optical process in Semiconductors (Prentice-Hall, New York, 1971) p.88

[17] F. I. Ezema and C. E. Okeke, Greenwich Journal of Science and Technology 3(2) (2003) 90

[18] H. Metin and R. Esen, Semicond. Sci. Technol. 18 (2003) 647

[19] J. Y. Choi, K. J. Kim, J. B. Yoo and D. Kim, Sol. Ener. 64(1-3) (1998) 41

[20] Lin. Su-Shia and Huang. Jow-Lay, Surface and Coating Technology 185(2-3) (2004) 222

[21] M. T. S. Nair and P. K. Nair, Semicond. Sci. Technol. 4 (1989) 191

[22] R. U. Osuji and C. E. Okeke, Nig. Journal of Sol. Ener. 12 (1993) 12

[23] F. C. Eze and C. E. Okeke, Materials Chemistry and Physics, 47 (1997) 31
[24] M. Theye, Thin film technology and applications in optical properties of thin films. K.L Chopra and L. K. Malhota (eds). ( Tata McGraw-Hill, New Delhi, 1985) p. 163

[25] M. Rusu, J. Salaoru and M. E. Popa, Internat. J. Modn. Phys. B. Cond. Mat. Phys. 18 (2004) 1287

[26] F. I. Ezema, J. University of Chemical Technology and Metallurgy 39(2) (2004) 225

[27] R. Rodrigo del, D. Basaure, R. Schrebler, H. Gomez and R. Cordova, Phys. Chem. B106(49) (2002) 12634

[28] M. Quijada, J. Ceme, J. R. Simpson, H. D. Drew, K. H. Ahn, A. J. Millis, R. Shreekala, R. Ramesh, M. Rajeswari and T. Venkatesan, Physical Review B 58(24) (1998) 99

[29] P. J. Sabestian and H. Hu, Adv. Mater. Opt. Electron. 4 (1994) 407

[30] J. Chen, W. Z. Shen, N. B. Chen, D. J. Qin and H. Z. Wu, J. Phys. Condens. Matter 15 (2003) 475

[31] Yano. Mitsuaki, Ken-Ichi Ogata, Fengping. Yan, Kazuto. Koike, Shigehiko. Sasa and Masataka. Inoue, Mat. Res. Soc. Symp. Proc. 744 (2003) 1

[32] E. Pentia, V. Draghici, G. Sarau, B. Mereu, L. Pintillie, F. Sava and M. Popeseu, J. Electrochem. Soc. 151(1) (2004) 729

[33] A. M. Salem, Appl. Phys. A74 (2002) 205

[34] A. Majumdar, H. Z. Xu, F. Zhao, L. Jayasingha, S. Khosravani, X. Lu, V. Kelkar, Z. Shi, Mat. Res. Soc. Symp. Proc. 770 (2003)

[35] Dhere. Ramesh, Tim. Gessert, Jie. Zhou, Sally. Asher, Joel. Pankow and Helio. Moutinho, Mat. Res. Soc. Symp. Proc. 763 (2003) 1

[36] A. K. Shwarsctein, T. F. Jaramillo, Sung-Hyeon. Baeck, M. Sushdhikh and E. W. McFarland, J. Electrochem. Soc. 153(7) (2006) 483 